Uniwersytet Mikolaja Kopernika w Toruniu

Katedra Marketingu, Handlu i Logistyki

Iwona Escher

\title{
POMIAR KIERUNKU I SIŁY MARKETINGOWEJ POSTAWY PRACOWNIKA - KOMPROMIS POMIĘDZY TEORIĄ A PRAKTYKĄ MARKETINGOWA
}

Z a rys treś ci. Tematyka niniejszego opracowania dotyka kwestii pomiaru wymiarów postaw (w tym kierunku i siły) oraz rozbieżności, jakie w tej kwestii pojawiają się w obszarze teorii i praktyki marketingowej. Głównym celem prowadzonych w nim rozważań jest zaproponowanie rozwiązań w zakresie metod i narzędzi pomiaru kierunku i siły marketingowej postawy pracownika, łączących oczekiwania teoretyków marketingu oraz badaczy prowadzących pomiary w konkretnych organizacjach. Bazą wyjściową do realizacji tak założonego celu uczyniono rozważania teoretyczne oraz doświadczenia badawcze z zakresu pomiaru wymiarów postaw opisywane w literaturze psychosocjologicznej oraz marketingowej.

S łow a kluczowe: marketingowa postawa pracownika, siła i kierunek postawy, pomiar siły i kierunku postawy.

\section{WSTĘP}

Od wielu lat na gruncie marketingowej dyscypliny, w rozważaniach nawiązujących do problematyki budowy oraz umacniania w organizacjach marketingowej bądź rynkowej orientacji, pojawia się pojęcie „marketingowej postawy pracowników”. Brak jednoznacznego opisu rozważanej zmiennej w warstwie teoretycznej przekłada się nie tylko na różnorodność i niejednoznaczność proponowanych dla niego ujęć, ale też na brak jednoznacznych propozycji odnośnie do metod i narzędzi pomiaru głównych wymiarów rozważanej postawy (tj. jej 
kierunku i siły ${ }^{1}$ ). Co ciekawe, opisane zaniedbania nie zniechęcają niektórych badaczy marketingowych do realizowania badań, w których „marketingowa postawa pracownika” (lub terminy do niej zbliżone) stanowi pojęcie kluczowe, ani też do budowania na ich podstawie wniosków, często nad wyraz odważnych i zdecydowanych.

Opisana sytuacja stanowi doskonały przykład na to, jak czasami teoria i praktyka marketingowa rozmijają się i jak próbuja, na własny i oderwany od siebie sposób, poradzić sobie z istniejącymi ograniczeniami. $\mathrm{Z}$ jednej strony bowiem, w teorii marketingu podkreśla się, iż z uwagi na olbrzymią rolę podsystemu społecznego w każdej organizacji winno się systematycznie identyfikować, rozumieć i kształtować szeroką gamę zmiennych opisujących jej pracowników (nawet jeśli większość z nich ma charakter niewidoczny lub jakościowy, związany z ich psychika), z drugiej strony, jak przedstawiono wcześniej, w tej samej teorii brakuje podpowiedzi, jak definiować operacyjnie owe zmienne (np. wspomnianą marketingową postawę pracownika), jak je mierzyć i jak interpretować uzyskane z ich pomiaru wyniki.

Z punktu widzenia poprawności metodologicznej przed przystąpieniem do „pomiaru” jakiejkolwiek postawy, w tym też rozważanej tutaj marketingowej postawy pracownika, należy ją najpierw teoretycznie zdefiniować za pomocą innych pojęć przyjętych za zrozumiałe (etap konceptualizacji), a następnie nadać jej definicję operacyjną (etap operacjonalizacji). Bez jednoznacznej definicji nie sposób opisać wymiarów tej postawy (w tym kierunku i siły) ani też przypisać im zewnętrznie uchwytnych, mierzalnych wyróżników (mowa o zestawie werbalnych i niewerbalnych reakcji poznawczych, emocjonalnych i behawioralnych stanowiących mierzalne przejawy wymiarów postaw). To z kolei uniemożliwia opracowanie kompleksowych propozycji metod i narzędzi pomiaru owych wymiarów i ich zastosowanie w konkretnym badaniu empirycznym. Oczywiste jest, iż przy obecnym stanie opisu marketingowej postawy pracownika w warstwie teoretycznej, braku jednoznacznej dla niej definicji, a nawet nazwy, nie jest możliwe dokonywanie rzetelnej i trafnej oceny jej kierunku i siły (także oceny innych jej wymiarów). Wiele z podejmowanych w tym zakresie badań należy więc uznać za działania realizowane w sprzeczności z podstawowymi założeniami teorii.

W świetle zaprezentowanych faktów widać wyraźnie, jak wielka jest potrzeba teoretycznego zdefiniowania rozważanej postawy, opisania jej podstawowych wymiarów (kierunku i siły), przypisania im mierzalnie uchwytnych wyróżników oraz wskazania możliwych sposobów ich pomiaru. Z uwagi na fakt, iż kwestia

\footnotetext{
${ }^{1}$ Kierunek i siła postawy to dwa wymiary postaw mierzone najczęściej w badaniach marketingowych (por. dalsza część niniejszego opracowania).
} 
definiowania marketingowej postawy pracownika, jej siły i kierunku oraz odpowiadających im reakcji wartościujących stanowiła tematykę wcześniejszych publikacji autorki, w niniejszym opracowaniu główny nacisk zostanie położony na kwestię ostatnią, związaną z obszarem pomiaru wymiarów rozważanej postawy. Podstawowym celem podjętych tu wysiłków nie jest jednak proponowanie jednoznacznych w tym zakresie rozstrzygnięć, ale wskazanie na możliwe drogi poszukiwania rozwiązania, na które czeka zarówno środowisko teoretyków, jak i praktyków marketingowych. Z oczywistych względów bazą wyjściową do realizacji tak założonych celów uczyniono rozważania dostępne w literaturze psychosocjologicznej oraz marketingowej.

\section{POMIAR POSTAWY CZY POMIAR WYMIARÓW POSTAWY?}

Postawa, zgodnie z poglądem podzielanym przez większość psychologów społecznych, jest względnie trwałą strukturą (lub dyspozycją do pojawiania się takiej struktury) procesów poznawczych, emocjonalnych i tendencji do zachowań, w której wyraża się określony stosunek osoby wobec obiektu (Mika, 1984, s. 116). Definicja ta nawiązuje do najpopularniejszego ujęcia struktury postawy, wywiedzionego z tzw. modelu trójskładnikowego, w myśl którego postawę budują jednocześnie trzy komponenty (emocjonalny, poznawczy oraz behawioralny).

Postawa jest w rzeczywistości pewnym skrótem (konstruktem) stosowanym dla oznaczenia zbioru powiązanych ze sobą obserwowalnych zjawisk. Pozostaje w określonej relacji do tych zjawisk, pomaga je porządkować oraz rozumieć, ale sama pozostaje zmienną nieobserwowalną (Babbie, 2003, s. 140-145). To oznacza, że nie istnieje coś takiego jak „pomiar postawy osoby X wobec obiektu Y”. Wprawdzie sformułowanie tego typu wydaje się naturalne i logiczne (zwłaszcza że podobnych znaleźć można w literaturze i praktyce wiele), to jednak należy zdawać sobie sprawę, że jest jedynie wygodnym skrótem myślowym badaczy. W rzeczywistości, gdy mowa o „pomiarze rozważanej postawy” - nie mierzy się postawy jako takiej, lecz mierzy się jej konkretne wymiary.

Każda postawa ma szereg wymiarów. Wśród nich literatura wymienia m.in.: treść przedmiotowa, zakres, złożoność, zwartość, stopień powiązania, trwałość, dostępność, kierunek i siłę (zob. Mądrzycki, 1970, s. 27-31; Mika, 1984, s. 118-121; Rosołowicz, 1998, s. 42). Dwa ostatnie wymiary należą do najczęściej poddawanych pomiarowi w obszarze badań marketingowych. Można zatem z dużym prawdopodobieństwem założyć, iż to właśnie do tych dwóch obszarów nawiązują teoretycy i praktycy marketingowi posługujący się sformułowaniami typu „pomiar postawy danej osoby wobec jakiegoś obiektu”. 
Skoro, jak wcześniej wskazano, postawa jest zmienną nieobserwowalną, aby określić konkretny jej wymiar (w tym: kierunek i siłę), należy ustalić, a następnie poddać pomiarowi zewnętrzne i empirycznie uchwytne wyróżniki owego wymiaru. Wskazówkę odnośnie do tego, co jest mierzalnym wyróżnikiem wymiaru postawy, dostarcza koncepcja obszarów uzewnętrzniania się wymiarów postawy, nawiązująca do opisanego wyżej modelu trójskładnikowego (zob. Mądrzycki, 1970, s. 25-26; Manstead i in., 2001, s. 642; Światowy, 2002, s. 179). Zgodnie z nią, wymiary postawy (w tym kierunek i siła) uzewnętrzniają się w szerokiej gamie werbalnych i niewerbalnych reakcji afektywnych, poznawczych lub behawioralnych (wyrażanie emocji, uczuć, nastrojów wobec obiektu postawy; wyrażanie myśli, przekonań, przypuszczeń, wątpliwości o obiekcie postawy; wyrażanie intencji behawioralnych wobec obiektu postawy; fizjologiczne i ekspresyjne reakcje na obiekt postawy; reakcje percepcyjne na obiekt postawy; obserwowalne działanie wobec obiektu postawy).

Opisana koncepcja obszarów uzewnętrzniania się wymiarów postawy stanowi cenną wskazówkę odnośnie do tego, które konkretnie cechy danej osoby, czyli mierzalnie uchwytne zmienne (nazywane też w literaturze reakcjami wartościującymi), należy poddawać pomiarowi, aby możliwe było określenie wartości poszczególnych wymiarów badanej postawy (w tym jej kierunku i si$ł^{2}$ ). Wnioskując o konkretnym wymiarze badanej postawy w oparciu o pomiar wskazanych powyżej rodzajów i typów reakcji wartościujących, należy jednak uwzględniać fakt, iż w niektórych sytuacjach mogą one nie w pełni odzwierciedlać rzeczywiste wartości jej wymiarów. Jak pisze Kenrick i in. (2002, s. 100), ludzie miewają niekiedy powody, aby nie przyznawać się do swoich prawdziwych uczuć lub też odczuwają problemy przy wyrażaniu ich słowami (dotyczy reakcji afektywno-werbalnych). Co więcej, znaczna grupa zachowań danej osoby (tj. jej reakcji behawioralno-niewerbalnych) może być kształtowana przez wiele czynników jednocześnie i tylko część z nich może się wiązać bezpośrednio z kierunkiem i siłą posiadanej postawy ${ }^{3}$. Należy także pamiętać, że różni ludzie mogą różnie wyrażać swoim zachowaniem tę samą postawę (jej kierunek czy siłę). To z kolei sugeruje, że prawdopodobieństwo uzyskania spójnych wyników co do

2 Kierunek postawy uwidacznia się w reakcjach wartościujących zdecydowanie pozytywnych, poprzez coraz mniej pozytywne, obojętne (o ile przyjąć, że występuje obojętny kierunek postawy), częściowo negatywne, aż do jednoznacznie negatywnych. Siła postawy jest blisko powiązana z kierunkiem. Postawy krańcowo pozytywne i krańcowo negatywne określa się jako silniejsze od postaw umiarkowanych (zob.: Nowak, 1973, s. 24-29; Mika, 1984, s. 118-121; Nowak, 1985, s. 246).

3 Kierunek podejmowanego wobec obiektu zachowania może być niezgodny z kierunkiem posiadanej postawy m.in. na skutek działania czynników trzecich, tzw. moderatorów zgodności. Szerzej na ich temat piszą Mądrzycki (1970, s. 89-97) oraz Kenrick i in. (2002, s. 112). 
faktycznych wartości wymiarów postawy badanej osoby (w tym rozważanej tu marketingowej postawy pracownika) jest tym większe, im szerszy zakres reakcji wartościujących poddany jest pomiarowi i im więcej metod i technik zbierania danych wykorzystany zostanie w ich pomiarze (metody ankietowe, wywiad indywidualny, wywiad grupowy, pogłębiony wywiad indywidualny, obserwacja, pomiary fizjologiczne, techniki projekcyjne). Tak sformułowany postulat wydaje się minimalizować większość błędów związanych z ustalaniem poszukiwanych wymiarów postawy badanej osoby, aczkolwiek niektórzy badacze twierdza, że czasami związek trzech rodzajów reakcji wartościujących (emocjonalnej, poznawczej i behawioralnej) na ten sam obiekt bywa na tyle słaby lub zależny od tak wielu dodatkowych czynników, że nawet rozszerzony zakres metod badawczych i mierzonych reakcji wartościujących może być niewystarczający, aby określić faktyczne wymiary postawy danej osoby (zob. Wojciszke, 2001, s. 79).

\section{POMIAR KIERUNKU I SIŁY POSTAW W PRAKTYCE}

Sformułowany w punkcie 1 niniejszego opracowania postulat odnośnie do realizowania pomiaru kierunku i siły postaw w oparciu o jak najszerszy zakres reakcji wartościujących i przy wykorzystaniu jak największej liczby różnorodnych metod i technik zbierania danych w praktyce rzadko jest realizowany. Pogłębiona analiza opracowań badawczych z zakresu pomiaru kierunku i siły różnorodnych postaw wyraźnie dowodzi, iż przy ich określaniu rzadko sięga się po pomiar reakcji niewerbalnych ${ }^{4}$, a identyfikacja pozostałych reakcji werbalnych oparta jest zazwyczaj jedynie na pomiarach realizowanych metodą ankiety bądź standaryzowanego wywiadu indywidualnego. Zastosowane w ich ramach skale pomiarowe umożliwiają określenie kierunku i siły postawy w oparciu o pomiar opinii wyrażanych z różnym stopniem akceptacji ${ }^{5}$. Wprawdzie, w obliczu wcześniej prezentowanych treści, tego typu rozwiązania wydają się dużym uproszczeniem, to jednak przyznać należy, iż nie stanowią wyjątku, lecz reprezentują raczej

${ }^{4}$ Odstępowanie od pomiarów reakcji niewerbalnych wynika z licznych przeszkód, wśród których wymienia się m.in.: dużą pracochłonność i kosztowność tego typu badań; trudność określenia niewerbalnych zachowań wobec pewnych obiektów postawy; rzadkie pojawianie się niektórych zachowań bądź brak społecznej zgody na ich ujawnianie się; występowanie zachowań niezgodnych z kierunkiem postawy z racji oddziaływania innych, obok postawy, czynników; niemożność oceny kierunku wyrażanych reakcji fizjologicznych (dotyczy reakcji afektywno-niewerbalnych) itp. zob. Mika, 1975, s. 68-71; 1984, s. 129-130.

5 Opinii nie należy utożsamiać jedynie z przekonaniem, gdyż może ona również wyrażać przypuszczenie i wątpliwość, zawierać przewidywanie zdarzeń oraz odzwierciedlać komponent uczuciowo-motywacyjny postawy (uczucia, życzenia, pragnienia, dążenia) - zob. Mądrzycki, 1970, s. 26. 
ogólny kierunek, w którym podąża warsztat badawczy psychologów, socjologów, a w konsekwencji także badaczy marketingowych.

Jest oczywiste, że taka praktyka dokonywania pomiaru kierunku i siły postaw w dużym stopniu utrudnia (a nawet czyni niemożliwa) ocenę wszystkich trzech komponentów postawy opisanych w modelu trójskładnikowym. W skrajnych sytuacjach, idąc „na skróty”, badacze budują wnioski o kierunku i sile określonej postawy, stosując skale, które w rzeczywistości służą ocenie tylko któregoś z jej komponentów (np. komponentu behawioralnego - por. przykład 1).

Prawdą jest, że można też spotkać propozycje pomiaru kierunku i siły postawy uwzględniające jednocześnie istnienie jej trzech komponentów. Nie wszystkie wydają się jednak spełniać do końca opisane powyżej oczekiwania. W przypadku procedury zaprezentowanej w przykładzie 2 wątpliwości wzbudzają m.in.: zastosowanie prostych skal do pomiaru poszczególnych komponentów postawy, konstrukcja skali przypisanej komponentowi afektywnemu (stwierdzenie drugie i trzecie wydają się odnosić do komponentu poznawczego, a nie emocjonalnego) oraz brak zgodności pomiędzy trzema zastosowanymi skalami pomiarowymi (co stanowić może wyraźne utrudnienie na etapie wnioskowania o kierunku i sile postawy rozpatrywanej całościowo).

Przykład 1. Skale dystansu społecznego służące do pomiaru tendencji behawioralnej ${ }^{6}$

\begin{tabular}{|c|c|}
\hline $\begin{array}{l}\text { Przykład 1.1. Obiekt postawy: grupa etniczna X } \\
\text { Do której z podanych sytuacji społecznych } \\
\text { dopuściłaby Pani/dopuściłby Pan członka } \\
\text { grupy etnicznej X (ani nie najgorszego, ani nie } \\
\text { najlepszego)? } \\
\text { do bliskiego związku przez małżeństwo } \\
\square \text { do klubu jako bliskiego przyjaciela } \\
\square \text { jak sąsiada na tej samej ulicy } \\
\square \text { jako osobę zatrudnioną w moim zawodzie } \\
\square \text { jako obywatela mojego kraju } \\
\square \text { tylko jako turystę w moim kraju } \\
\square \text { należałoby usunąć go z mojego kraju }\end{array}$ & $\begin{array}{l}\text { Przykład 1.2. Obiekt postawy: osoba X } \\
\qquad \begin{array}{l}\text { W jakim stopniu chciałaby Pani/chciałby Pan } \\
\text { zbliżyć się do osoby X lub jej unikać? }\end{array} \\
\square \text { zdecydowanie nie chciałbym się z nią kontaktować } \\
\square \text { wolałbym się z nią nie spotykać } \\
\square \text { spotkanie z nią jest mi zupełnie obojętne } \\
\square \text { chętnie zobaczyłbym ją czasem na wydziale } \\
\square \text { byłoby mi przyjemnie z nią porozmawiać } \\
\square \text { byłoby mi przyjemnie spotkać się z nią poza } \\
\text { uczelnią } \\
\square \text { chciałbym wykonywać z nią jakieś zadanie } \\
\text { (wspólną pracę) } \\
\square \text { chciałbym, żeby ona przyszła do mnie ze swoimi } \\
\text { sprawami } \\
\square \text { chciałbym porozmawiać z nią o moich ważnych } \\
\text { sprawach osobistych }\end{array}$ \\
\hline
\end{tabular}

Źródło: opracowanie własne na podstawie: Mika, 1975, s. 159-160; Manstead i in., 2001, s. 148-149; Babbie, 2003, s. 190-191.

${ }^{6}$ Skale dystansu społecznego (jak sama nazwa wskazuje) odnoszą się przede wszystkim do tych postaw, których obiektem są inne osoby (względnie przedmioty fizyczne). 
Przykład 2. Pomiar trzech komponentów postawy wobec kawy Nescafe Mild

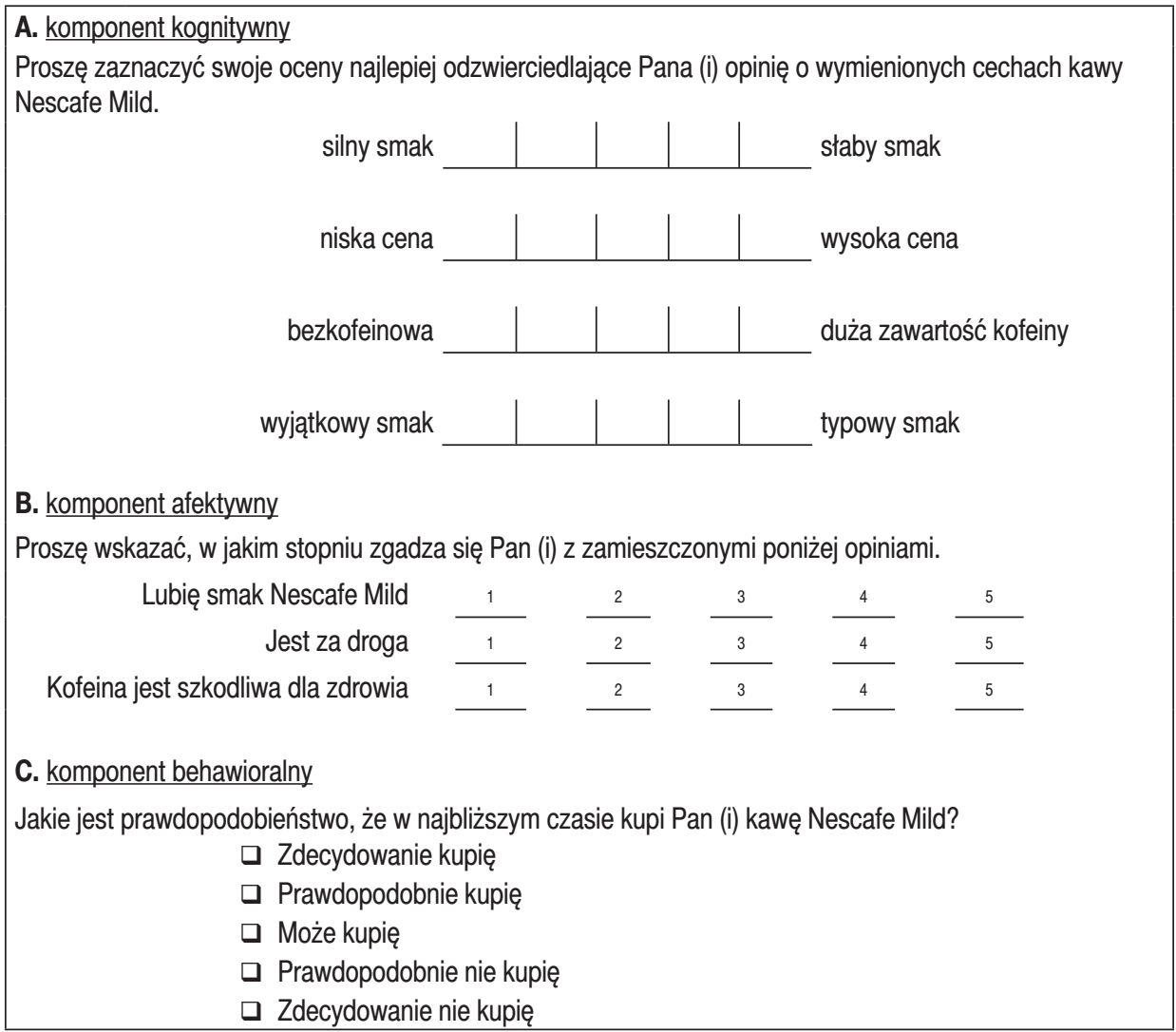

Źródło: opracowanie własne na podstawie: Rosołowicz, 1998, s. 45.

Pozostając przy zawężonym zakresie badanych reakcji wartościujących i stosowanych metod zbierania danych, niektórzy badacze próbują przełamać ograniczenia prostych skal pomiarowych (takich jak zaprezentowane w przykładach 1 i 2) poprzez wykorzystanie do pomiaru kierunku i siły postaw jednej, specjalnie skonstruowanej, skali złożonej. Do najczęściej stosowanych w tym celu należą: skala równych interwałów Thurstone’a oraz skala Likerta. Wydaje się, że taki wybór stanowi dobry kompromis pomiędzy oczekiwaniami teoretyków i możliwościami badawczymi praktyków. Jak podkreśla Sagan (1998, s. 94), w badaniach postaw (w domyśle, ich kierunku i siły) należy stosować tylko skale wielopozycyjne (skale złożone), postawa jest bowiem konstruktem zbyt złożonym, aby można było ją mierzyć za pomocą jednej pozycji (jednej pojedynczej skali). Posługiwanie się skalami złożonymi pozwala wykrywać nawet 
stosunkowo subtelne różnice w postawach, czego nie można uczynić, wykorzystując bardziej prymitywne narzędzia, tj. pojedyncze skale pomiarowe. Zaleta ta jest szczególnie istotna wówczas, gdy próbuje się opisać proces zmiany postawy, a jednocześnie zmiany te są nieduże (Mika, 1984, s. 137). Przewaga skal złożonych widoczna jest również w tym, że szczególne cechy konkretnej pozycji (będącej elementem skali złożonej) nie są w stanie w znaczący sposób wpływać na ostateczny wynik pomiaru, podczas gdy szczególne właściwości skali prostej mogą mieć duży wpływ na wnioski wyciągane z badań (Manstead i in., 2001, s. 374; Babbie, 2003, s. 173).

Z drugiej jednak strony, podobnie jak w przypadku prostych skal, pod adresem większości znanych skal złożonych można zgłosić zastrzeżenia odnośnie do braku wyraźnego nawiązania do teoretycznej koncepcji trójskładnikowego modelu postawy. Uzasadnieniem dla stosowania tego typu rozwiązań może być jednak pogląd (zob. Nowak, 1973, s. 27), według którego postawy są w gruncie rzeczy (jeśli wszystkie trzy komponenty są w nich zarysowane) tak ściśle powiązanymi zbitkami dyspozycji afektywnych, dyspozycji behawioralnych i przekonań o naturze obiektu postawy, iż określenie granic pomiędzy nimi na etapie pomiaru jest bardzo utrudnione (tzn. trudne jest ustalenie, gdzie kończy się czysto deskryptywna wiedza o obiekcie postawy czy wyobrażenia o jego naturze, a zaczynają się emocje i oceny, i z kolei, gdzie kończy się wiedza i oceny obiektu, a zaczyna gotowość, zamiar czy poczucie powinności podejmowania określonych wobec obiektu zachowań). Tego typu wyjaśnienie jest głównym argumentem przemawiającym na korzyść tak powszechnej praktyki określania kierunku i siły postaw jedynie w oparciu o pomiar opinii wyrażanych z różnym stopniem akceptacji.

\section{SKALE ZŁOŻONE STOSOWANE W POMIARACH KIERUNKU I SIŁY POSTAW}

Jak wspomniano w części 2, skala równych interwałów Thurstone’a oraz skala Likerta należą do najczęściej wykorzystywanych w pomiarach kierunku i siły postaw. Ich konstrukcja opiera się na pewnych ogólnych założeniach, nawiązujących bezpośrednio do zagadnienia kierunku i siły postawy (Mika, 1984, s. 137-138). Założenia te są następujące:

1. Zawarty w postawach stosunek do obiektu można ujmować w kategoriach przychylności, co pozwala na określenie kierunku postawy;

2. Wspomniana przychylność jest stopniowalna, co pozwala określić siłę postawy (oznacza to, że wszystkie potencjalne postawy, jak i wszystkich nosicieli postawy można uszeregować na continuum od najbardziej do najmniej przychylnych obiektowi postawy); 
3. Poszczególnym stwierdzeniom stanowiącym element skali odpowiadają określone stopnie przychylności;

4. Każdemu stopniowi przychylności można przypisać określoną liczbę;

5. Wybór danego stwierdzenia przez osobę badaną lub zadeklarowanie, w jakim stopniu z tym stwierdzeniem się zgadza, umożliwia przypisanie wartości liczbowej jej indywidualnej postawie.

Szczególną uwagę należy zwrócić na trzy ostatnie założenia, gdyż, choć powszechnie przyjmowane w obszarze praktyki, wzbudzają zrozumiałe kontrowersje w środowisku teoretyków, zwłaszcza statystyków.

Wychodząc od ogólnych rozważań, należy zauważyć, iż skale będące elementem instrumentów pomiarowych mogą mieć charakter nominalny, porządkowy, przedziałowy (interwałowy) lub stosunkowy (proporcjonalny). Wybór konkretnej skali zależy od przedmiotu (obiektu) pomiaru, czyli mierzonej cechy. Postawa, jako obiekt pomiaru, ze swej natury nie jest zmienną ilościowa. W związku z tym do pomiaru kierunku i siły postawy wykorzystuje się przede wszystkim słabsze (jakościowe) skale porządkowe. Jednak na etapie analizy zebranych danych te same zmienne zaczyna traktować się jako zmienne mierzone na skali silniejszej. Poszczególnym stopniom skal porządkowych przypisuje się równe odległości, choć w rzeczywistości nie można ich określić - nie występuje tu bowiem jednostka miary, która dawałaby możliwość wnioskowania o wielkości kolejnych różnic pomiędzy nimi.

Jak podkreślają ortodoksyjni statystycy, równość narysowanych odległości nie może stanowić automatycznego przyzwolenia do traktowania skal porządkowych jako skal silniejszych i stosowania do analizy danych z nich otrzymanych działań przynależnych skalom silniejszym. Jeśli wprowadza się równe odległości w instrumentach pomiarowych, to jedynie po to, aby ominąć przypadki zasugerowania respondentom określonego wyboru na skali. W tym miejscu poglądy purystów metodologicznych i badaczy prowadzących pomiary na gruncie psychosocjologii i badań marketingowych wyraźnie się rozmijają. Druga z wymienionych grup powszechnie interpretuje dane z pomiaru porządkowego $\mathrm{w}$ kategoriach danych uzyskanych z pomiaru silniejszego, zakładając, że różnice pomiędzy stopniami skal są tak niewielkie, iż nie wpływa to na obniżenie poprawności wyników analizy, albo też uznając, że mierzona zmienna jakościowa reprezentuje pewną ukrytą zmienną mierzalną i fakt jej pomiaru za pomocą skali porządkowej jest tylko efektem niedoskonałości narzędzi badawczych (por. Górniak, Wachnicki, 2000, s. 115-116; Kaczmarczyk, 2002, s. 91). Wsparciem dla takich założeń są wyniki studiów symulacyjnych, które dowodzą iż traktowanie zmiennych porządkowych tak jak przedziałowych w wielu przypadkach nie prowadzi do dużych błędów (por. Churchill, 2002, s. 424). Poszukiwanie kolejnych argumentów pozwalających na wprowadzanie tego typu uproszczeń jest niezmiernie istotne, 
otwiera bowiem drogę do stosowania wielu technik statystycznych zarezerwowanych dla zmiennych mierzalnych.

Opisane podejście upraszczające jest szczególnie bronione w badaniach społecznych, psychologii i marketingu, czyli dziedzinach, w których nieczęsto pojawia się możliwość użycia skal mocniejszych niż porządkowe. Jak piszą Górniak, Wachnicki (2000, s. 115-116), mimo sporu toczonego od lat z teoretykami i ortodoksyjnymi statystykami, praktyka już go rozstrzygnęła na korzyść podejścia liberalnego. W pomiarach wymiarów postaw traktowanie kodów zmiennych porządkowych tak, jakby miały one sens liczbowy, jest praktyką zwyczajowo obowiązującą (Wieczorkowska i in., 2003, s. 88-91). Churchill (2002, s. 423) pisze, że takie stanowisko wydaje się rozsądne, nawet jeśli nie jest całkiem poprawne.

Dwie omawiane tu skale złożone (skala Thurstone’a, skala Likerta) opierają się na opisanym podejściu i choć obie są popularne w pomiarach kierunku i siły postaw, to jednak większa część badaczy wydaje się opowiadać za skalą Likerta. W literaturze podkreśla się między innymi, iż skala Likerta przezwycięża słabości punktacji i braku możliwości wyrażania intensywności odczuć skali Thurstone’a, a dodatkowo jest w porównaniu z nią prostsza, bardziej przejrzysta i o wiele mniej pracochłonna (Mika, 1984, s. 145-147; Mayntz i in., 1985, s. 70-75; Kowal, 1998, s. 43; Manstead i in., 2001, s. 373). Jej istotną zaletą jest też fakt, iż redukcja opinii niespełniających założenia o jednowymiarowości skali może być w równym stopniu przeprowadzona po badaniu pilotażowym, jak i po badaniu właściwym (w takim wypadku stwierdzenia, które okażą się wieloznaczne nie są brane pod uwagę przy opracowywaniu wyników) ${ }^{7}$.

7 Zaznaczyć jednak trzeba, że pomimo licznych walorów i popularności, skala Likerta ma też słabości. Jedną z nich jest kwestia interpretowania wyników środkowych. Ich uzyskanie może bowiem świadczyć o posiadaniu postawy neutralnej (jeśli zgodzić się z poglądem, że takowa postawa w ogóle istnieje), ale też o wewnętrznej sprzeczności w postawie. Dodatkowo, może być wynikiem omyłkowego wskazania odpowiedzi przez osobę badaną (w wyniku mechanicznego ustosunkowywania się do stwierdzeń odpowiadających skrajnym stopniom przychylności wobec obiektu postawy) lub rezultatem uchylania się od odpowiedzi na część stwierdzeń zawartych w skali (Mika, 1984, s. 147). Dostępna literatura psychosocjologiczna i marketingowa nie dostarcza wskazówek, jak radzić sobie z opisanymi trudnościami i jak w takich przypadkach wnioskować o kierunku i sile mierzonej postawy. W związku z tym każdy badacz samodzielnie stara się rozstrzygnąć opisane kwestie, przygotowując własne propozycje rozwiązania opisanego problemu. 


\section{POMIAR KIERUNKU I SIŁY MARKETINGOWEJ POSTAWY PRACOWNIKA - WYBÓR METODY ZBIERANIA DANYCH I SKALI POMIAROWEJ}

Jak wspomniano we wstępie do niniejszego opracowania, teoria marketingu nie oferuje gotowych narzędzi do pomiaru kierunku i siły marketingowej postawy pracowników, do tej pory nie wypracowała bowiem nawet jednej nazwy dla rozważanej zmiennej ani jej definicyjnego ujęcia. W tej sytuacji pierwszym krokiem do realizacji celu zapisanego w tytule niniejszej części musi stać się zaproponowanie definicji marketingowej postawy pracownika. Próbę taką autorka podjęła i opisała szerzej w innych swoich publikacjach, stąd (z uwagi na ograniczenia formalne) na potrzeby niniejszych rozważań zaprezentowany zostanie jedynie jej efekt końcowy w postaci stworzonej propozycji definicyjnego ujęcia rozważanej zmiennej. Ujęcie to zostało zbudowane w oparciu o koncepcje postawy dostępne w literaturze psychosocjologicznej oraz wyniki eksploracyjnego badania jakościowego, przeprowadzonego metodą pogłębionych wywiadów indywidualnych na grupie 30 osób posiadających, z racji wykonywanego zawodu bądź wykształcenia, przynajmniej elementarną wiedzę z zakresu marketingu. Łącząc odkryte dziedziny omawianej zmiennej, ustalono, iż marketingowa postawa pracownika jest względnie trwałą strukturą (lub dyspozycją do pojawiania się takiej struktury) procesów poznawczych, emocjonalnych i tendencji do zachowań, w której wyraża się pozytywny bądź negatywny stosunek pracownika wobec faktu uzależnienia sprawności działania organizacji oraz własnej ścieżki zawodowej od wprowadzania w organizacji zmian ukierunkowanych na utrzymanie korzystnych relacji z zewnętrznymi i wewnętrznymi klientami organizacji (w tym zmian w sferze dotychczasowych zadań, kwalifikacji, zachowań samego pracownika itp.).

Zaproponowane ujęcie jest jedynie pierwszym krokiem w kierunku pomniejszenia istniejącej luki w marketingowej dyscyplinie i z pewnością nie oddaje całego bogactwa znaczeń i aspektów rozważanej zmiennej. Niemniej jednak, na potrzeby niniejszego opracowania, powala na kontynuowanie rozważań na temat możliwych metod i narzędzi pomiaru kierunku i siły opisywanej postawy, tym bardziej że w przekonaniu autorki nie stracą one na znaczeniu nawet wówczas, gdy pojawi się inna (doskonalsza) propozycja jej definicyjnego ujęcia.

Oczywiste jest, iż poszukując propozycji dla pomiaru kierunku i siły marketingowej postawy pracownika, nie sposób ignorować rozwiązań, które już dziś wykorzystywane są w zakresie pomiarów dwóch wymienionych wyżej wymiarów postaw na gruncie psychosocjologii i badań marketingowych (por. rozważania 
w części 2 oraz 3 niniejszego opracowania). Wzorując się na zaprezentowanej tam procedurze, można przyjąć, iż poszukiwane narzędzie do pomiaru kierunku i siły marketingowej postawy pracownika winno zbliżać się do jednej z dwóch opisanych tam skal złożonych (skala równych interwałów Thurstone’a lub skala Likerta), przy czym na korzyść skali Likerta przemawiają, obok powszechności jej zastosowania, także inne podkreślane w części 3 zalety. Do jej wyboru skłaniają również dodatkowe argumenty. W przypadku pomiaru kierunku i siły marketingowej postawy pracownika należy się spodziewać, iż pomiar innych (pozawerbalnych) reakcji wartościujących pracownika mógłby być utrudniony, a nawet niemożliwy. Trudno, dla przykładu, oczekiwać, że organizacje dysponują narzędziami pomiarowymi umożliwiającymi rejestrację fizjologicznych i percepcyjnych reakcji pracownika albo też że powszechnie i systematycznie prowadzą naturalną obserwację jego zachowania (tj. jego niewerbalnych reakcji behawioralnych).

W przypadku zastosowania skali Likerta w pierwszym rzędzie rozstrzygnięcia wymaga kwestia wyboru metody zbierania danych. W obliczu opisanych powyżej ograniczeń (ale też specyfiki rozważanej skali złożonej) badaczowi nie pozostaje wiele możliwości - ma tu do dyspozycji bądź jedną z metod ankietowych, bądź osobisty wywiad kwestionariuszowy. Wydaje się, iż stosunkowo najlepszym rozwiązaniem jest w tej sytuacji wybór metod ankietowych, a w ich ramach przede wszystkim - ankiety bezpośredniej lub (ewentualnie) ankiety audytoryjnej, gdyż dają one szansę na pozyskanie najmniej zniekształconych danych (w obu dochodzi do minimalizacji wpływu niekorzystnych czynników związanych z sytuacją pomiaru na sposób udzielania odpowiedzi przy równoczesnym utrzymaniu odpowiedniego stopnia kontroli procesu zbierania danych). Wprawdzie wywiad osobisty zapewnia znacznie większą kontrolę pomiaru, daje możliwość wychwycenia na bieżąco wszelkich niezgodności pomiędzy udzielanymi przez respondentów odpowiedziami, eliminuje błędy związane z omyłkowym wskazywaniem odpowiedzi czy też celowym lub przypadkowym ominięciem wybranych pozycji skali, jednak bezpośredni kontakt badacza z respondentem sprzyjać może pojawieniu się wielu niekorzystnych zjawisk (np. tzw. efektu ankietera) ${ }^{8}$. Dodatkowo, w przypadku wywiadu osobistego wzrasta niebezpieczeństwo udzielania odpowiedzi będących doraźnymi reakcjami respondentów zaskoczonych określonym pytaniem (zwłaszcza jeśli dotyczy ono sprawy, nad którą nie zastanawiali się wcześniej), podczas gdy w sytuacji pomiaru ankietowego mają więcej czasu na refleksję. To powstrzymuje ich przed powtarzaniem opinii gotowej (znanej,

8 O efekcie ankietera piszą m.in. Sztabiński, 1995, s. 159-168; 1997, s. 115-134, oraz Lutyńska, 1997, s. 53-71; 1998, s. 17-36. 
zasłyszanej od innych) bądź przyjmowaniem stanowiska wytworzonego na miejscu w chwili pomiaru (stanowisko takie, ze swej natury, jest zwykle nadmiernie uproszczone, jednostronne i nie oddaje rzeczywistej, wewnętrznie trwałej struktury przekonań, emocji i intencji behawioralnych osób badanych) ${ }^{9}$.

Podobnie jak wybór metody zbierania danych, również decyzja o postaci skali do pomiaru kierunku i siły marketingowej postawy pracownika nie może być pochopna. Jak piszą Goode, Hatt (1985, s. 260), przystępując do budowy jakiejkolwiek skali do pomiaru kierunku i siły postawy, należy liczyć się z tym, iż w rzeczywistości:

- istnieje nieskończenie wiele aspektów (i odpowiadających im pozycji skali), w których może wyrazić się kierunek i siła owej postawy;

- $\quad$ każdej zaproponowanej skali można zarzucić, iż nie uwzględnia wszystkich możliwych aspektów, każdy badacz spośród olbrzymiej ich liczby wybiera bowiem tylko niektóre, inne zaś (świadomie bądź nieświadomie) pomija;

- dla każdego z wybranych aspektów można dobierać nieskończenie wiele wskaźników (ekwiwalentów empirycznych);

- każdy badacz spośród nieskończonej liczby wskaźników (ekwiwalentów empirycznych) wybiera tylko niektóre.

Powyższe stwierdzenia wyraźnie sugerują, iż jakakolwiek skala do pomiaru kierunku i siły marketingowej postawy pracownika (czy zaproponowana przez autorkę niniejszego opracowania, czy przez jakiegokolwiek innego badacza), w gruncie rzeczy stanowić może narzędzie umożliwiające jedynie w pewnym przybliżeniu orzekanie o rzeczywistym kierunku i sile marketingowej postawy pracownika. Jak wspomniano wyżej, skale takie zawsze będą bowiem obejmować niektóre tylko aspekty omawianej zmiennej, a dalej - niektóre tylko wskaźniki tych aspektów, wybrane spośród nieskończenie licznego zbioru. Jak pisze Churchill (2002, s. 475), badacz musi mieć ciagłą świadomość, że pomiar jest wąskim wyobrażeniem badanej kategorii (zmiennej), a jego rezultat będzie się zmieniał, będąc fluktuacją włączonych do pomiaru wskaźników.

Kończąc prowadzone rozważania, należy podkreślić, iż nieodzownym elementem praktycznego zastosowania zbudowanej przez badacza skali do pomiaru

9 Wybór metody ankietowej nie oznacza automatycznie, iż w każdych warunkach wypada ona korzystniej w porównaniu z metodą osobistego wywiadu kwestionariuszowego. Z punktu widzenia problematyki konkretnego badania cechy rozważanych tutaj dwóch grup metod pomiaru sondażowego mogą być ich atutami bądź słabościami. Metody ankietowe umożliwiają pomiar przekonań; wywiad doskonale sprawdza się przy pomiarze spontanicznych reakcji, a zatem każda z metod mierzy inną sferę świadomości respondenta - zob. Sztabiński, 1997, s. 118-130. 
kierunku i siły marketingowej postawy pracowników (jak każdej innej złożonej skali pomiarowej) winna być zawsze ocena jej rzetelności oraz trafności. Powyższa uwaga jest o tyle istotna, że ten etap wykorzystania skal złożonych bywa nagminnie marginalizowany w literaturze, a w konsekwencji zaniedbywany na etapie badań empirycznych.

\section{PODSUMOWANIE}

Marketingowa postawa pracownika, jak każda inna postawa, ma szereg wymiarów, w tym kierunek i siłę - dwa wymiary postaw najczęściej poddawane pomiarowi w badaniach marketingowych. Jak podpowiada teoria, aby dokonać pomiaru kierunku i siły marketingowej postawy pracownika, niezbędne jest w pierwszej kolejności zdefiniowanie zewnętrznych wyróżników owych wymiarów (tj. całej gamy werbalnych, jak i niewerbalnych reakcji wartościujących o charakterze afektywnym, poznawczym i behawioralnym), a następnie dokonanie ich pomiaru za pomocą możliwie najszerszego zbioru różnorodnych metod i narzędzi badawczych. Specyfika rozważanej postawy, olbrzymie bogactwo możliwych reakcji wartościujących stanowiących zewnętrzne wyróżniki jej kierunku i siły oraz potencjalne trudności pomiaru niektórych z nich powodują jednak, iż spełnienie sformułowanego powyżej postulatu jest w praktyce niemożliwe. Kompromisowym rozwiązaniem może być w tej sytuacji zastosowanie rozwiązania, które już dziś wykorzystuje wielu psychologów, socjologów oraz badaczy marketingowych w zakresie pomiaru kierunku i siły interesujących ich postaw. Mowa tu o wykorzystaniu specjalnie skonstruowanych skal złożonych. Wśród nich na uwagę zasługuje skala Likerta, która jest bardzo często stosowana przez badaczy postaw, a dodatkowo przezwycięża mankamenty innych znanych skal złożonych. Niezależnie jednak od ostatecznego wyboru pamiętać trzeba o tym, iż jakakolwiek skala zaproponowana przez badacza w gruncie rzeczy będzie zawsze narzędziem pozwalającym zmierzyć jedynie wycinek nieskończonego bogactwa aspektów, w których może wyrazić się rzeczywisty kierunek i siła marketingowej postawy danego pracownika. 


\section{LITERATURA}

Babbie E. (2003), Badania społeczne w praktyce, PWN, Warszawa.

Churchill G. A. (2002), Badania marketingowe. Podstawy metodologiczne, PWN, Warszawa.

Goode W. J., Hatt P. K. (1985), Podstawowe problemy pomiaru, [w:] Nowak S., Metodologia badań spolecznych, PWN, Warszawa.

Górniak J., Wachnicki J. (2000), SPSS PL for Windows. Pierwsze kroki w analizie danych, SPSS Polska, Kraków.

Kaczmarczyk S. (2002), Badania marketingowe. Metody i techniki, PWE, Warszawa.

Kenrick D. T., Neuberg S. L., Cialdini R. B. (2002), Psychologia społeczna, GWP, Gdańsk.

Kowal J. (1998), Metody statystyczne w badaniach sondażowych, PWN, Warszawa-Wrocław.

Lutyńska K. (1997), Wpływ ankieterski w pierwszej fazie badań kwestionariuszowych, „Ask”, nr 1-2, 53-71.

Lutyńska K. (1998), „Strategie” i postawy wspótczesnych ankieterów a reakcje i nowe obawy respondentów, „Ask”, nr 7, 17-36.

Manstead A. S. R., Hewstone M., Fiske S. T., Hogg M. A., Reis H. T., Semin G. R. (2001), Psychologia społeczna. Encyklopedia Blackwella, JS, Warszawa.

Mayntz R., Holm K., Hübner P. (1985), Wprowadzenie do metod socjologii empirycznej, PWN, Warszawa.

Mądrzycki T. (1970), Psychologiczne prawidłowości kształtowania się postaw, PZWS, Warszawa.

Mika S. (1975), Wstęp do psychologii społecznej, PWN, Warszawa.

Mika S. (1984), Psychologia społeczna, PWN, Warszawa.

Nowak S. (1973), Pojęcie postawy w teoriach i stosowanych badaniach spolecznych, [w:] Nowak S. (red.), Teorie postaw, PWN, Warszawa.

Nowak S. (1985), Metodologia badań społecznych, PWN, Warszawa.

Rosołowicz Ł. (1998), Postawa to podstawa, „Marketing w Praktyce”, nr 5, 42.

Sagan A. (1998), Badania marketingowe. Podstawowe kierunki, Wydawnictwo AE w Krakowie, Kraków.

Sztabiński F. (1997), Ankieta pocztowa i wywiad kwestionariuszowy, IFiS PAN, Warszawa.

Sztabiński P. B. (1995), Ankieter jako źródło zniekształceń w procesie badawczym, „Ask”, nr 2, 159-168.

Światowy G. (2002), Pomiar zmiennych jakościowych, [w:] Mazurek-Łopacińska K. (red.), Badania marketingowe. Podstawowe metody i obszary zastosowań, Wydawnictwo AE we Wrocławiu, Wrocław.

Wieczorkowska G., Kochański P., Eljaszuk M. (2003), Statystyka. Wprowadzenie do analizy danych sondażowych i eksperymentalnych, Scholar, Warszawa.

Wojciszke B. (2001), Postawy i ich zmiana, [w:] Streulau J. (red.), Psychologia. Jednostka w społeczeństwie i elementy psychologii stosowanej, GWP, Gdańsk. 


\title{
MEASUREMENT OF THE DIRECTION \\ AND INTENSITY OF THE MARKETING ATTITUDE OF EMPLOYEES - A COMPROMISE BETWEEN MARKETING THEORY AND PRACTICE
}

\begin{abstract}
The subject of this paper refers to the questions of the measurement of various dimensions of attitudes (especially theirs direction and intensity) and differences which exist in theory and practice. The main purpose of the article is to give proposals of methods and scales which can be used to measure the direction and intensity of the marketing attitude of employee, and which could join expectations of marketing theorists and marketing researchers.
\end{abstract}

Keywords: marketing attitude of employees, direction and intensity of attitude, measurement of the direction and intensity of attitude. 